\title{
Continuous Membrane Bioreactor (CMBR) to Produce Nanoparticles from Milk Components
}

\author{
Vanessa Nieto-Nieto ${ }^{1}$, Silvia Amaya-Llano ${ }^{2}$ and Lech Ozimek ${ }^{1}$ \\ ${ }^{1}$ Department of Agricultural, Food and Nutritional Science, \\ University of Alberta, Edmonton, Alberta, \\ 2Programa de Posgrado en Alimentos del Centro de la República (PROPAC), \\ Universidad Autónoma de Querétaro, \\ Querétaro Qro. \\ ${ }^{1}$ Canada \\ ${ }^{2}$ México
}

\section{Introduction}

Membrane technology has been used in the dairy industry as alternative to some unit operations since the early 1970s. The new applications of membranes were often due to the development of membrane science. The commercial availability of Nanofiltration membranes allowed the demonstration of some biological activities in milk and whey peptide sequences (Pouliot 2008). Nanotechnology is used in different stages of the membrane development and has gain great interest among the agro-food sector and it involves the manufacture, processing and applications of structure devices and systems controlling the shape and size of particles at the nanometer scale (Garcia et al., 2010). The size range that holds so much interest is typically from $100 \mathrm{~nm}$ down to the atomic level; approximately $0.2 \mathrm{~nm}$, because in this range material can have different and enhanced properties compared with the same material at a large size. As the particle size decreases, a greater proportion of atoms are found at the surface compared to inside. For example, a particle size of $30 \mathrm{~nm}$ has a $5 \%$ of its atoms on the surface, at $10 \mathrm{~nm} 20 \%$, and at $3 \mathrm{~nm} 50 \%$ of the atoms are in surface. Thus a nanoparticle (NP) has a much greater surface area per unit mass compared with larger particles, leading to grater reactivity. In addition to the surface area effect, quantum effect can also govern the properties of matter as size is reduced to the nanoscale, affecting the optical, electrical and magnetic behaviour of materials (Thassu et al., 2007).

The application of nanotechnology in the food industry covers many aspects, such as food safety, packaging material, disease treatment, delivery systems, bioavailabilty, and new tools for molecular and cellular biology and new material for pathogen detection. However the four major areas in food industry to benefit from nanotechnology are the development of new functional materials, micro and nanoscale processing, new product development and the design of nanotracers and nanosensors for food safety and biosecurity (Moraru et al., 2003). 
It is the interest of this chapter to discuss the production of bioactive NPs from food commodities and to explain how nanotechnology in a continuos membrane bioreactor (CMBR) and in particular nanofiltration processes can be employed to alter food products.

The term "bioactive food component" refers to nonessential biomolecules that are present in foods and exhibit the capacity to modulate one or more metabolic processes, which results in the promotion of better health (Swanson, 2003).

A major strategy for the delivery of these components into food is through encapsulation, which consists in coating one or several components (core) within a secondary material (encapsulant). This is used to mask the color and taste of nutrients, and to protect sensitive nutrients during processing, storage, and transportation (Kuo, 2010).

Bioactive compounds are added into food looking to provide health benefits and protection as antioxidants and anti-aging agents, reducing the risk of cardiovascular diseases or with the intention to boost the nutritional content of the product.

The application of nanotechnology in the food industry is still in a developing stage, however in recent years; research has been carried out in order to formulate food-grade encapsulants to enable the delivery of desirable bioactive compounds through the food supply.

Due to their sub-cellular size, NPs offer promising means of improving the bioavailability of bioactive compounds, especially poorly soluble substances such as functional lipids (e.g. carotenoids, phytosterols, $\omega-3$ fatty acids), natural antioxidants, and other compounds that are widely used as active ingredients in various food products. NPs can dramatically prolong compound residence time in the gastrointestinal tract by decreasing the influence of intestinal clearance mechanisms and increasing the surface available to interact with the biological support. They can also penetrate deeply into tissues through fine capillaries, cross the epithelial lining fenestration and are generally taken up efficiently by cells, thus allowing efficient delivery of active compounds to target sites in the body (Chen et al., 2006).

\section{Nanomaterials}

NP can be produced from a variety of different materials, from metals like gold and silver, organic solvents or some food derived ingredients. The use of food-grade ingredients is generally accepted by the regulatory agencies, has shown to exert good results as nanomaterials and would contribute to dissipate the fear among consumers given the fact that these polymers are part of the human diet.

Food-grade proteins and polysaccharides, such as whey protein, casein, gelatine, soy protein, zein, starch, cellulose, and various other hydrocolloids are used. In addition, they may contain other components, such as water, lipids, minerals and sugars (Jones \& McClements, 2010).

\subsection{Lipid-based nanoparticles}

Lipid-based nanoparticles can encapsulate compounds with different solublities, but in particular these particles are useful carriers of poorly water soluble compounds. The term "lipid" is used in a broad sense to include phospholipids, triacylglycerides, fatty acids, steroids and waxes (Peters et al., 2011). 
Different structures have been proposed using lipids as a main encapsulant constituent some of the most commonly discussed structures are: liposomes and solid lipid nanoparticles (SLN).

Liposomes are spherical, self-closed structures formed by one or more concentric lipid bilayers with an encapsulated aqueous phase in the center and between the bi-layers (Pisal et al., 2010). They can accommodate hydrophilic, lipophilic and amphiphilic compounds in their aqueous and or lipid compartment. These structures are used as carrier systems for the protection of bioactive compounds by improving their solubility and bioavailability and preventing their unwanted interaction with other molecules (Mozafari, 2010).

The preparation of SLN is carried out at high temperatures, generally above the melting point of the lipid component used and further a cooling stage is required to solidify the lipid (Bunjes, 2010). Some disadvantages of SLN are the limited loading capacity of the bioactive compound and expulsion of the bioactive compound during storage. In order to overcome these drawbacks Nanostructured Lipid Carriers (NLC) were developed (Souto \& Muller, 2006). NLC are composed of oily droplets embedded in a solid lipid matrix, this provides more stability with a controlled nanostructure that improves the bioactive compound loading and firmly incorporates the bioactive compound during storage (Shidhaye et al., 2008).

Lipid-based nanoparticles, have been used to contain different bioactive compounds such as vitamins (a-tocopherol) (Shukat \& Relkin, 2011), $\beta$-carotene (Hentschel et al., 2008 ), and $\omega$ 3-fatty acids (Muchow et al., 2009).

\subsection{Protein-based nanoparticles}

Proteins have very good gelling and emulsifying properties and for this reason they are widely used as encapsulating material. Thanks to the consistent primary structure of proteins a wide variety of nutrients can be incorporated allowing them to form complexes with polysaccharides, lipids or other biopolymers. In order to improve bioavailability, the food industry is currently attempting to increase the circulation time of conventional nanocarriers in the gastrointestinal tract, notable by surface coating with protein (Chen et al., 2006).

Food proteins can undergo denaturation due to exposure to high temperatures or pressure. The resulting un-denaturated product can then re-assemble, building a new structure (Bengoechea et al., 2011). Or well if proteins are combined with polysaccharides, these materials can form biopolymeric nanostructured particles by complexation (Ron et al., 2010).

When a globular protein becomes denaturated its physical and chemical interaction change appreciably through exposure of nonpolar and sulphur containing groups that were originally present within the compact interior of the globular protein. Consequently, denaturated proteins have a greater tendency to aggregate, irreversibly, with each other through hydrophobic bonding and disulfide bond formation (Jones \& McClements, 2010).

Nanoemulsions are dispersions of nanoscale droplets as the result of mixing two immiscible phases, made by the application of high shear. The rupture of droplets may be achieved by ultra-sonication or microfluidisation. The amount of surfactant requires to stabilise nanoemulsion is greater (Augustin \& Hemar, 2009). To prevent the droplet from recombining into larger droplets a thin encapsulating layer is introduced to help stabilize 
the system; this layer is traditionally made up of proteins or phospholipids which act as surfactants (Sanguansri \& Augustin. 2006).

A particular case of protein based NP are nanotubes derived from partially hydrolyzed alactalbumin. This nanostructure is very stable and strong and has a $8.7 \mathrm{~nm}$ cavity that can be used to contain bioactive compounds (Graveland-Bikker, 2006).

Milk proteins such as casein, a-lactalbumin and $\beta$-lactoglobuline, lactoferrin, bovine serum albumin, have been widely used in the development of nanostructures with very different applications. However their physicochemical properties facilitate their functionality as vehicle of bioactive compounds (Livney, 2010). However the use of protein in the building of nanostructures is not limited to milk proteins, vegetable proteins have been used as it is the case of pea protein (Donsi et al., 2010) and zein (Podaralla and Perumal et al.,2010).

\subsection{Polysaccharide-based nanoparticles}

Polysaccharides are used to improve texture in foods or as stabilizer agents in emulsions, and some of the most commonly used are: starch, xanthan gum, pectin, alginate and chitosan. In combination with proteins and lipids, nanostructed particles can be formed.

According to their structural characteristics, these polysaccharide-based nanoparticles are prepared mainly by four mechanisms: covalent crosslinking, ionic crosslinking, polyelectrolyte complexation, and self-assembly of hydrophobically modified polysaccharides, Liu et al. (2008) reviewed these four mechanisms in detail. Of these methods polyelectrtolyte complexetion is commonly used in the preparation of nanoparticles containing food derived bioactive compounds.

When proteins and polysaccharides carry an opposite charge, complex formation is driven by attractive electrostatic interactions between the two biopolymers (Augustin \& Sanguansri, 2009). Attractive interactions and complexation begin at values slightly above the protein's isoelectric point; further $\mathrm{pH}$ reduction induces greater complexation (Jones et al., 2010).

It is important to establish the electrical characteristics of the polysaccharide molecules used, since electrostatic interactions may be used to assemble specific biopolymer structures. The electrical charge on polysaccharide depends on the nature of the ionic groups along the chain background, as well as solution conditions. Some polysaccharides are neutral (starch, cellulose) some anionic (alignate, carrageenan, xanthan, gum Arabic) and some cationic (chitosan) (Matalanis et al., 2011).

Sugar beet pectin was used to produce a nanostructured system for stabilization, protection and delivery of hydrophobic bioactive compounds. For this, vitamin D was bounded to $\beta$ lactoglobulin, later a complex between the carrier and the polysaccharide of the opposite charge was formed. This system has been proposed for enrichment of clear and non-fat beverage (Ron et al., 2010).

\section{Nanotechnology and nanofiltration}

The application of membrane technology in the nanoscale range has increased as a result of the continuous application of nanotechnology in the food sector. In the same way that nanoparticles are produced as an encapsulated systems based on food ingredients and 
designed to have a broad range of applications, nanofiltration can be utilized as a nanoscale process to produce food ingredients with added value.

In the membrane based separation process, the driving force for material transport through selective membranes is a pressure difference, thus these processes are called pressure-driven membrane process, and such is the case of microfiltration (MF) and ultrafiltration (UF). In the case of nanofiltration (NF) a pressure difference is not the only driving force, selective removal of ions based on charge is another feature of this technology (Muthukumarappan \& Marella 2010). Thus the selective separation process results in nanometer scale products.

Nanofiltration membranes have apparent pore diameter between 0.5 and $5 \mathrm{~nm}$ and are capable of removing from water, both organic matter and ions of mineral salts (Goncharuk et al., 2011). In such way nanofiltration can separate components according to their molecular size without a change phase of the solvent; this avoids thermal damage and requires a lower consumption of energy (Darnoko \& Cheryan, 2006).

Nanofiltration is currently used to supply high quality drinking water (Goncharuk et al., 2011), desalting milk, whey and other dairy fluids (Pouliot, 2008), additionally a wide range of value added components can be obtained after a nanofiltration treatment.

\subsection{Membrane bioreactors in the nanoscale process}

Biocatalytic membrane reactors combine selective mass transport with chemical reactions, and the selective removal of products from the reaction site increases the conversion of product-inhibited or thermodynamically unfavorable reactions. Membrane reactors using biological catalysts can be used in production, processing and treatment operations (Giorno \& Drioli, 2000).

In a bioreactor, the conversion of raw materials into value added products is carried out by enzymatic hydrolysis; further, in combination with a NF membrane the separation of substrate and product will occurred; as the membrane will only allow the passage of certain components known as "permeate" (the product) and retains/rejects other components known as "retentate" (Muthukumarappan \& Marella, 2010) .

The use of biocatalysts for large-scale production is an important application because it enables biotransformations to be integrated into productive reaction cycles. Biocatalysts (e.g. enzymes, microorganisms and antibodies) can be used: (1) suspended in solution and compartmentalized by a membrane in a reaction vessel or (2) immobilized within the membrane matrix itself. In the first method, the system might consist of a traditional stirred tank reactor combined with a NF membrane-separation unit. In the second method, the NF membrane acts as a support for the catalyst and as a separation unit (Giorno \& Drioli, 2000).

Some of the advantages of the use of membrane bioreactor as a nanoscale process are that the catalytic/separation process (Giorno \& Drioli, 2000; Rios et al., 2004):

- does not require additives

- $\quad$ is able to function at moderate temperature and pressure

- reduces the formation of by-products

- catalytic enzymes are extremely efficient and selective compared with chemical catalysts. 
- $\quad$ the enzyme is retained and reused

- $\quad$ substrate/product inhibition is reduced

- the end product is free of enzyme

- one single step operation (reaction/separation).

However the use of NF membranes is not limited to the enzymatic membrane reactors. NF has been commonly used as a pre-concentration step in the milk processing operations in order to reduce the energy consumption in heat based treatments.

The whey that is obtained during cheese making with a very high mineral content, could be used for the manufacture of other valuable food ingredients such as whey protein concentrate and whey protein isolate, however the mineral content should be reduce to provide a higher quality. With NF the demineralization of whey can be achieve, since NF membranes are often used for separation of charged solutes (Suárez et al., 2009).

Thus, membrane technology at this scale can be used for (Vandanjon et al., 2007):

- Separation of high molecular weight component from low molecular weight components.

- Fractionation of products according to their molecular weight.

- Concentration of mixture or selected fractions

- Purification

Table 1. presents an overview of the NF processes that have been proposed in the food sector. NF has been used for concentration or purification of compounds with biological activity such as antioxidants, prebiotics and bioactive peptides. Alternatively NF has also been proposed for separation of valuable components such as lactose or undesirable components such as salts, biogenic amines, toxins or heavy metals.

\subsection{Recovery of compounds with antioxidant activity}

Concentration of bioactive compounds can be achieved by NF treatment, because this process does not require high temperatures in contrast to other concentration treatments such as evaporation. Thus, by using mild temperatures the functional properties of this temperature sensitive compounds are preserved (Benedetti et al., 2011).

Due to their beneficial effects on human health, Isoflavones were concentrated from soybean using a NF membrane. However in order to ensure a good yield and to avoid the fouling of the membrane due to the accumulation of fat globules in the membrane, defatted soy flour was used as raw material and the final results of this study showed that the nanofiltration process for the concentration of isoflavones is viable (Benedetti et al., 2011).

In order to separate low molecular weight, hydrophobic components, the nanofiltration membrane needs to meet certain characteristics that will be defined by the compound that is being recovered. Darnoko \& Cheryan (2006) selected a hydrophobic membrane to separate $\beta$-carotene from the palm methyl esters, increasing the concentration in from $0.45 \mathrm{~g} / \mathrm{L}$ to $1.88 \mathrm{~g} / \mathrm{L}(34)$.

Flavonoids and polyphenolic compounds from Sideritis scardica Griseb were concentrated up to 3-4 times. The concentrated extracts preserve their high antioxidant activity and could be used as a source of concentrated biologically active material. Also the separation of 
flavonoids form low molecular polyphenols was possible in base of their molecular weight difference (Tylkowski et al., 2010).

\begin{tabular}{|c|c|c|c|c|c|c|c|}
\hline $\begin{array}{l}\text { Separated } \\
\text { component }\end{array}$ & \begin{tabular}{|l|} 
Component \\
separated from
\end{tabular} & Membrane material & $\begin{array}{l}\text { NF } \\
\text { module }\end{array}$ & \begin{tabular}{|l} 
MWCO \\
$(\mathrm{Da})$
\end{tabular} & $\mathrm{T}\left({ }^{\circ} \mathrm{C}\right)$ & \begin{tabular}{|l}
$\begin{array}{l}\text { Pressure } \\
(\mathrm{kPa})\end{array}$ \\
\end{tabular} & Reference \\
\hline $\begin{array}{l}\text { Phenolic } \\
\text { compounds }\end{array}$ & $\begin{array}{l}\text { Aqueous mate } \\
\text { (Ilex } \\
\text { paraguariensis) } \\
\text { extract }\end{array}$ & & $\begin{array}{l}\text { Spiral } \\
\text { wound }\end{array}$ & $150-300$ & 25 & 690 & $\begin{array}{l}\text { Negrão } \\
\text { et al. } \\
2011\end{array}$ \\
\hline $\begin{array}{l}\text { Aroma and } \\
\text { protein }\end{array}$ & $\begin{array}{l}\text { Tuna cooking } \\
\text { juice }\end{array}$ & $\begin{array}{l}\text { Polyamide coated } \\
\text { with } \\
\text { polyesthersulfone }\end{array}$ & tubular & 400 & 40 & 3500 & $\begin{array}{l}\text { Walha et } \\
\text { al. } 2011\end{array}$ \\
\hline \multirow{6}{*}{ Anthocyanins } & \multirow{6}{*}{ Açai juice } & $\begin{array}{l}\text { Semi-aromatic } \\
\text { polyamide layer on } \\
\text { top of a } \\
\text { polysulphone } \\
\text { microporous } \\
\text { support }\end{array}$ & \multirow{6}{*}{$\begin{array}{l}\text { Plate } \\
\text { and } \\
\text { frame }\end{array}$} & & \multirow{6}{*}{35} & \multirow{6}{*}{$\begin{array}{l}1000 \\
1500 \\
2000 \\
3000\end{array}$} & \multirow{6}{*}{$\begin{array}{l}\text { Couto et } \\
\text { al. } 2011\end{array}$} \\
\hline & & \begin{tabular}{|l} 
Aromatic \\
polyamide
\end{tabular} & & & & & \\
\hline & & |------- & & $\sim 1000$ & & & \\
\hline & & Thin film & & & & & \\
\hline & & Thin film & & & & & \\
\hline & & Poliestersulfone & & $\sim 1000$ & & & \\
\hline $\begin{array}{l}\text { Fructooligo- } \\
\text { saccharides }\end{array}$ & $\begin{array}{l}\text { Sucrose from } \\
\text { sugar cane } \\
\text { molasses }\end{array}$ & |------- & $\begin{array}{l}\text { Spiral } \\
\text { wound }\end{array}$ & 400 & 95 & 4000 & $\begin{array}{l}\text { Kuhn et } \\
\text { al. } 2010\end{array}$ \\
\hline \multirow{2}{*}{ Alcohol } & \multirow{2}{*}{ Wine } & \multirow{2}{*}{ Polyamide } & \multirow{2}{*}{ |------ } & 300 & \multirow{2}{*}{45} & \begin{tabular}{|l|}
500 \\
1500 \\
\end{tabular} & \multirow{2}{*}{$\begin{array}{l}\text { Takacs et } \\
\text { al. } 2010\end{array}$} \\
\hline & & & & 400 & & $\begin{array}{l}1000 \\
2000\end{array}$ & \\
\hline Biogenic amines & Model solution & ----- & Flat & 1000 & 70 & 3500 & $\begin{array}{l}\text { Sabaté et } \\
\text { al. } 2008\end{array}$ \\
\hline Mineral salts & Whey & $\begin{array}{l}\text { Aromatic } \\
\text { polyamide }\end{array}$ & $\begin{array}{l}\text { Spiral } \\
\text { wound }\end{array}$ & 300 & & $\begin{array}{l}500- \\
2400\end{array}$ & $\begin{array}{l}\text { Pan et al. } \\
2011\end{array}$ \\
\hline \multirow[b]{2}{*}{$\begin{array}{l}\text { Cyanobacterial } \\
\text { toxins }\end{array}$} & \multirow[b]{2}{*}{ Drinking water } & \multirow{2}{*}{$\begin{array}{l}\text { Polyamide } \\
\text { composite with a } \\
\text { microporous } \\
\text { supporting layer }\end{array}$} & \multirow[b]{2}{*}{$\begin{array}{l}\text { Flat- } \\
\text { sheet }\end{array}$} & 200 & & \multirow[b]{2}{*}{8000} & \multirow[b]{2}{*}{$\begin{array}{l}\text { Coral et } \\
\text { al. } 2011\end{array}$} \\
\hline & & & & 300 & & & \\
\hline
\end{tabular}

Table 1. Nanofiltratrion processes proposed for concentration, purification or separation of relevant food ingredients.

Conidi et al. (2011) proposed an integrated membrane process based on the preliminary UF of enzymaticaly depictinised juice with a $100 \mathrm{kDa}$ membrane to remove suspended solids followed by a NF step with a 450 Da membrane. The separation and concentration of 
polyphenols of the bergamot juice was possible. The retentate contained the phenolic compounds, which showed a high total antioxidant activity.

Crude rice bran is a by-product of rice milling, rich in phytochemicals with high nutritional value such as $\gamma$-oryzanol. A two-step nanofiltration system was set up for enrichment of this phytochemical in rice oil. The first membrane stage, produced the separation of glycerides and $\gamma$-oryzanol, promoting the oil enrichment in this phytochemical. In the second membrane stage the oil was refined to acceptable consumption levels of free fatty acids and its $\gamma$-oryzanol content was further enhanced. The antioxidant activity of the resulting product oil possessed a significantly higher antioxidant capacity than the feed oil $(45.9,19.3$ $\mu \mathrm{mol}$ Trolox/g respectively). This results show that the product generated through NF membrane process has a superior nutritional value (Sereewatthanawut et al., 2011).

\subsection{Oligosaccharides}

Oligosaccharides (OS) are not digested in the human small intestine and stimulate the growth of bacterial flora, hence they are used as prebiotics (Botelho-Cuhna et al., 2010). The resulting commercial OS products contain plenty of side resultants of low molecular weight sugars such as glucose, fructose, sucrose, galactose and lactose, lowering the performance of the end product. Therefore, high purity of OS products is required (Feng et al., 2009). Thus NF seems to be a viable alternative for industrial scale purification of OS mixtures.

Many recent reports of the application of membrane technology to produce and concentrate OS have been published using different sources such as whey protein concentrate (Barile et al., 2009), caprine milk (Martinez-Ferez et al., 2008), rice husk (Vegas et al., 2008) and soybean waste water (Wang et al., 2009).

In a recent study, apple pomace samples were subjected to simultaneous saccharification and fermentation resulting in a mixture of lactic acid and OS. Lactic acid was further removed by ion exchange and the mixture was processed with two sequential steps using NF membranes in order to refine and concentrate the following OS: glucooligosaccharides, galactooligosaccharides, xylooligosaccharides and arabinooligosaccharides. More than $90 \%$ of low molecular weight compounds (residual lactic acid, arabinose and $\mathrm{NaCl}$ ) were removed from the solution. On the other hand, just a limited part of the OS was lost in the permeate. As a result of the treatments, the mass fraction of the OS in the final product increased from 0.360 up to $0.677 \mathrm{~kg} / \mathrm{kg}$ of non-volatile compounds. These results confirm that coupling two NF stages (discontinuous diafiltration followed by concentration) is a suitable alternative for obtaining OS concentrates. The refined product obtained in this work showed degrees of purity in the range reported for commercial OS and was assayed for its prebiotic potential and the results showed the promotion of beneficial bacterial growth (Gullón et al., 2011).

Eucalyptus wood-derived xylooligosaccharides were obtained using UF and NF membranes (1-50 kDa) for separation and concentration. The UF unit was used to separate OS from higher molecular weight products or to fractionate OS of different degree of polimerization. In addition a NF unit was used for concentrating liquors and/or for removing undesired low molecular weight compounds, such as monomeric sugars or phenolic compounds, increasing the xylooligosaccharide concentration 3.8 times (Gullón et al., 2008). 
In other cases the separation process can be primarily intended to recover the low molecular weight sugars, such is the case of lactulose, which is very useful in the treatment of chronic constipation and is normally produced by isomerization of lactose using hydroxide/boric acid forming a complex. This complex can be split by changing conditions from basic to acidic and the borate is converted into $\mathrm{NaCl}$ and $\mathrm{H}_{3} \mathrm{BO}_{3}$. NF was used as an effective method for the desalination of lactulose syrup, thus the disaccharides (lactulose and lactose) were retained by the membrane in the presence of high concentrations of $\mathrm{NaCl}$ and $\mathrm{H}_{3} \mathrm{BO}_{3}$ in the syrup. In this way NF provides a commercial alternative to chromatography for concentration and purification (Zhang et al., 2011).

NF has been used in the winemaking for sugar control, by reducing the sugar concentration in must before fermentation with the purpose to reduce the alcohol content in wine. For this García-Martín et al. (2010) proposed a two successive NF steps for sugar removal. The musts obtained were mixed with untreated must or the retentate of the first NF stage, in order to reduce the alcoholic content by $2^{\circ}$. With this treatment other compound such as polyphenols, anthocyanins, catechins and tannins were partially removed and slight changes in color and aroma were observed.

A goats' milk product enriched in oligosaccharides (more than $80 \%$ ), lactose and salts-free was obtained following the two-stage tangential filtration process by Martinez-Ferez et al., (2006). Tubular ceramic membranes with molecular mass cut-offs of 50 (ultrafiltration) and 1 $\mathrm{kDa}$ (nanofiltration), respectively, were employed and 15 new oligosaccharide structures (4 neutral and 11 acidic), were identified. Goat's milk is a suitable source of oligosaccharides for applications in human nutrition due to their prebiotic and anti-infective properties.

Nanofiltration membranes can be used for purifying galactooligosaccharides (GOS) products from the monosaccharide hydrolysis products, glucose and galactose. According to Gosling et al., (2010), up to $88 \%$ of the di- and oligosaccharides were recovered from a commercial GOS mixture using a nanofiltration membrane with only $19 \%$ of the monosaccharides remaining in the retentate stream (Goulas et al., 2003). Catarino et al., (2008) investigated the fractionation of saccharide mixtures with calcium using ultrafiltration and nanofiltration processes and reported that saccharide fractionation was enhanced in the presence of calcium. Feng et al., (2009) reported the separation of sugar solutions in total recycle mode operations using nanofiltration membranes and the process resulted in oligosaccharides yield of $70 \%$ and purity of $54 \%$. These results show nanofiltration as an alternative process to industrial chromatography.

\subsection{Bioactive peptides}

Controlled enzymatic hydrolysis of proteins produces smaller peptidic fractions, which can exert a positive effect upon health. These fractions have been defined as bioactive peptides (Hartmann \& Meisel, 2007) and NF processes are particularly useful for separation of peptides due to the suitable molecular weight cut-off and because of the electrochemical effects, which play an important role in the case of charged molecules (Saxena et al., 2009).

Fish protein hydrolysates were produced and then submitted to a two-stage treatment (UF/NF) to obtain fractions with increased activity. In this study 4 major fractions were obtained. Size chromatography was used to characterize the peptide composition in each fraction. Within some fractions it was possible to find a wide size distribution and not only the 
expected size (Bourseau et al., 2009). Other similar reports using fish protein as a substrate in a UF/NF fractionation system have been reported (Picot, 2010; Vandanjon et al., 2009).

Milk proteins have been widely studied as a source of bioactive peptides with a broad range of activities, for this reason Ting et al. (2007) proposed a NF treatment for the fractionation of peptides derived from whey protein. In this work, peptides were selectively separated, based on their charge and size. NF separation of peptides and amino acids is very dependent on physicochemical parameters such as $\mathrm{pH}$ and ionic strength. At $\mathrm{pH}$ 9, acidic peptides carry a net negative charge. Since both the peptides and the membrane are negatively charged at this $\mathrm{pH}$, it is probable that electrostatic repulsion between the membrane and the acidic peptides prevented the peptides from permeating the membrane, meanwhile the basic peptides which were positively charged at this $\mathrm{pH}$ were present in the permeate.

Fractionation of a $\beta$-lactoglobulin ( $\beta$-LG) peptide mixture by nanofiltration (NF) membranes was investigated by Lapointe et al., (2003). Peptide mixture was prepared by tryptic hydrolysis of commercial $\beta$-LG followed by ultrafiltration (UF) for enzyme removal. In this paper, important change in NF selectivity as affected by hydrodynamic conditions and recirculation time via possible peptide-peptide interactions occurring in the so-called weakly attached layer were reported. Roufik et al., (2007) showed that the hypotensive peptide $\beta$-lactoglobulin ( $\beta$-Lg) f142-148, known as lactokinin, bind to bovine $\beta$-lactoglobulin variant $A(\beta-\operatorname{Lg} A)$ and this complex could delay the hydrolysis of this peptide by digestive enzymes.

The separation of peptides contained in rapeseed protein hydrolysate using UF/NF membranes was studied by Tessier et al. (2006). This process was also based on selective separation depending on the peptide and membrane charge. As in the previous example peptides with the same charge as the membrane (co-ions) were concentrated in the retentate whereas peptides with the opposite charge (counter-ions) were able to get through the membrane in the permeate. A pre-treatment step by acid precipitation to remove high molar mass substances was followed by the UF step ( $3 \mathrm{kDa})$, in which the concentration of small peptides was allowed. Later the mixture of small peptides was desalted using a NF unit to assess the influence of ionic strength on the fractionation selectivity. The results showed that changes in $\mathrm{pH}$ and/or ionic strength modified the nature and the intensity of electrostatic interactions between co-ions, counter-ions and membrane. Thus the control of $\mathrm{pH}$ and ionic strength should be key parameter in the selective separation process using NF membranes. Butylina et al., (2006) described the fractionation and further isolation and characterisation of peptides and proteins present in sweet whey by means of ultrafiltration using a regenerated cellulose membrane with a nominal molar mass cut-off value of $10 \mathrm{~kg} / \mathrm{mol}$ and nanofiltration through sulphonated polyether sulphone membrane with a cut-off of 1 $\mathrm{kg} / \mathrm{mol}$. The concentration of whey proteins was done below the critical flux. The sieving coefficients for the whey components (proteins, lactose and salts) were estimated. Whey proteins were completely rejected by the ultrafiltration membrane. Nanofiltration of whey permeates obtained after ultrafiltration was conducted at two $\mathrm{pH}$ values (9.5 and 3.0) that corresponded to the different charged states of the membrane and of the peptides. The transmission of peptides, amino acids and lactose was found to be mainly affected by the permeability of the fouling layer. The selectivity of the nanofiltration membranes toward peptides compared to lactose was calculated as 0.82 and 6.81 at $\mathrm{pH} 9.5$ and 3.0, respectively. 


\subsection{Other applications}

\subsubsection{Fusel alcohols}

Although fusel alcohols provide flavour in rice spirits, a high concentration of these compounds, can lead to off-flavors, cloudy appearance and cause headaches and dizziness. Based on this, NF was proposed to remove fusel alcohols from rice spirits. The best removal results were observed with a 150-300 Da cut-off and an operating pressure of $488.95 \mathrm{kPa}$. For these conditions the remaining fusel alcohols content decreased to $2.54 \mathrm{~g} / \mathrm{L}$. The alcohol content, soluble solids content and $\mathrm{pH}$ (organic acids) varied slightly in the rice spirits processed with NF, however the sensory evaluation results showed that the NF treatment, improved the taste and clarity of rice spirits. Thus NF treatment effectively improved the wine quality (Hsieh et al., 2010).

\subsubsection{Alternative sweeteners}

A new alternative non-caloric sweetener can be produce from Stevia rebaudiana. The production of this sweetener could involve the use of organic solvents and methanol and ethanol. For this reason a membrane based process has been proposed to manufacture this sweetener. It is possible to use a NF membrane process as a post-treatment or polishing stage after applying a previous concentration treatment. This is the case of a recent study, in which an integrated process with a microfiltration, ultrafiltration and nanofiltration membrane stage was used for the purification of this sweetener (Vanneste et al., 2011).

\subsubsection{Soy sauce}

Soy sauce with a reduced salt content was obtained after a NF treatment (150 Da) for removal of $\mathrm{NaCl}$ and recovery of nutritional components such as amino acid and fragrance from raw soy sauce. The process consisted in a dilution step followed by concentration and then diafiltration. This mode of operation showed the least processing time and least water consumption, along with a high salt removal and high nutrient retention. The permeate produced in soy sauce desalination could be either reused as processing water or as feed to produce light color soy sauce, all the materials including $\mathrm{NaCl}$, amino acids and water could be fully utilized. Consequently, this process was proposed as an alternative to produce soy sauce with low sodium content (Luo et al., 2009).

\section{Conclusion}

In consideration of the growing interest in promoting health through food, there is a continuous development of food-grade delivery systems to encapsulate, protect and deliver bioactive compounds (i.e. antioxidants, vitamins, bioactive peptides, antimicrobials).

Thus, there is now the possibility to produce food for a healthier population and improve its health and wellness through nanoscale technology; because of this, the "nano-food" market is expected to grow very positively within the next few years.

Materials such as proteins, polysaccharides and lipids have shown to exert good results as nanomaterials and would contribute to create less fear among consumers given the fact that these polymers are part of the human diet. 
As part of the nanotechnology involved in the food processing, operations such as nanofiltration represent a useful alternative for the separation, concentration, fractionation and purification of food components with added value since many of them can exert a beneficial effect upon health.

Nanofiltration in combination with controlled hydrolysis also provides an interesting alternative for production of bioactive compounds derived from food ingredients with some advantages such as the use of mild temperatures, the reuse of the enzymes, the final product free of enzyme or other compounds, making this operation economically attractive and highly likely to be used at an industrial scale.

\section{Acknowledgment}

This work was supported by Consejo Nacional de Ciencia y Tecnología (CONACyT) as part of the scholarship to pursue T.V. Nieto-Nieto Doctoral work.

\section{References}

Acosta, E. (2009). Bioavailability of nanoparticles in nutrient and nutraceutical delivery. Current Opinion in Colloid E Interface Science, 14(1), 3-15.

Augustin, M. A., \& Hemar, Y. (2009). Nano- and micro-structured assemblies for encapsulation of food ingredients. Chemical Society Reviews, 38(4), 902-912.

Augustin, M. A., \& Sanguansri, P. (2009). Nanostructured materials in the food industry. In Advances in food and nutrition research, Taylor, S.L. (Ed.), (pp. 183-213) Academic Press.

Barile, D., Tao, N., Lebrilla, C. B., Coisson, J., Arlorio, M., \& German, J. B. (2009). Permeate from cheese whey ultrafiltration is a source of milk oligosaccharides. International Dairy Journal, 19(9), 524-530.

Benedetti, S., Prudêncio, E. S., Mandarino, J. M. G., Rezzadori, K., \& Petrus, J. C. C. (2011). Concentration of soybean isoflavones by nanofiltration and the effects of thermal treatments on the concentrate. Food Research International, In Press, Corrected Proof

Bengoechea, C., Peinado, I., \& McClements, D. J. (2011). Formation of protein nanoparticles by controlled heat treatment of lactoferrin: Factors affecting particle characteristics. Food Hydrocolloids, 25(5), 1354-1360.

Botelho-Cunha, V. A., Mateus, M., Petrus, J. C. C., \& de Pinho, M. N. (2010). Tailoring the enzymatic synthesis and nanofiltration fractionation of galacto-oligosaccharides. Biochemical Engineering Journal, 50(1-2), 29-36.

Bourseau, P., Vandanjon, L., Jaouen, P., Chaplain-Derouiniot, M., Massé, A., Guérard, F., Chabeaud, A., Fouchereau-Péron, M., Le Gal, Y., Ravalleec-Plé, R., Bergé, J.-P., Picot, L., Piot, J.-M., Batista, I., Thorkelsson, G., Delannoy, C., Jakobsen, G., \& Johansson, I. (2009). Fractionation of fish protein hydrolysates by ultrafiltration and nanofiltration: Impact on peptidic populations. Desalination, 244(1-3), 303-320.

Bunjes, H. (2010). Lipid nanoparticles for the delivery of poorly water-soluble drugs. Journal of Pharmacy and Pharmacology, 62(11), 1637-1645.

Butylina, S., Luque, S., \& Nyström, M. (2006). Fractionation of whey-derived peptides using a combination of ultrafiltration and nanofiltration. Journal of Membrane Science, 280(1/2), 418-426.

Catarino, I., Minhalma, M., Beal, L. L., Mateus, M., \& de Pinho, M. N. (2008). Assessment of saccharide fractionation by ultrafiltration and nanofiltration. Journal of Membrane Science, 312(1-2), 34-40. 
Chen, L. Y., Remondetto, G. E., \& Subirade, M. (2006) Food protein-based materials as nutraceutical delivery systems. Trends in Food Science \& Technology, 17(5):272-83.

Conidi, C., Cassano, A., \& Drioli, E. (2011). A membrane-based study for the recovery of polyphenols from bergamot juice. Journal of Membrane Science, 375(1-2), 182-190.

Coral, L. A., de, O. P., Bassetti, F. d. J., \& Lapolli, F. R. (2011). Nanofiltration membranes applied to the removal of saxitoxin and congeners. Desalination $\mathcal{E}$ Water Treatment, 27(1-3), 8-17.

Couto, D. S., Dornier, M., Pallet, D., Reynes, M., Dijoux, D., Freitas, S. P., et al. (2011). Evaluation of nanofiltration membranes for the retention of anthocyanins of açai (euterpe oleracea mart.) juice. Desalination \& Water Treatment, 27(1-3), 108-113.

Darnoko, D., \& Cheryan, M. (2006). Carotenoids from red palm methyl esters by nanofiltration. Journal of the American Oil Chemists' Society, 83(4), 365-370.

Donsi, F., Senatore, B., Huang, Q. R., \& Ferrari, G. (2010). Development of novel pea proteinbased nanoemulsions for delivery of nutraceuticals. Journal of Agricultural and Food Chemistry, 58(19):10653-10660.

Feng, Y. M., Chang, X. L., Wang, W. H., \& Ma, R. Y. (2009). Separation of galactooligosaccharides mixture by nanofiltration. Journal of the Taiwan Institute of Chemical Engineers, 40(3), 326-332.

Garcia, M., Forbe, T., \& Gonzalez, E. (2010). Potential applications of nanotechnology in the agro-food sector. Ciencia e Tecnologia De Alimentos, 30(3), 573-581.

García-Martín, N., Perez-Magariño, S., Ortega-Heras, M., González-Huerta, C., Mihnea, M., González-Sanjosé, M. L., Palacio, L., Prádanos, P., \& Hernández, A. (2010). Sugar reduction in musts with nanofiltration membranes to obtain low alcohol-content wines. Separation and Purification Technology, 76(2), 158-170.

Giorno, L., \& Drioli, E. (2000). Biocatalytic membrane reactors: Applications and perspectives. Trends in biotechnology, 18(8):339-349.

Goncharuk, V. V., Kavitskaya, A. A., \& Skil'skaya, M. D. (2011). Nanofiltration in drinking water supply. Journal of Water Chemistry and Technology, 33(1), 37-54.

Gosling, A., Stevens, G., Barber, A., Kentish, S., \& Gras, S. (2010). Recent advances refining galactooligosaccharide production from lactose. Food Chemistry, 121(2), 307-318.

Goulas, A. K., Grandison, A. S., \& Rastall, R. A. (2003). Fractionation of oligosaccharides by nanofiltration. Journal of the Science of Food and Agriculture, 83(7), 675-680.

Goulas, A. K., Kapasakalidis, P. G., Sinclair, H. R., Rastall, R. A., \& Grandison, A. S. (2002). Purification of oligosaccharides by nanofiltration. Journal of Membrane Science, 209(1), 321-335.

Graveland-Bikker, J. F., Schaap, I. A. T., Schmidt, C. F., \& De Kruif, C. G. (2006). Structural and mechanical study of a self-assembling protein nanotube. Nano Letters, 6(4), 616-621.

Gullón, B., Gullón, P., Sanz, Y., Alonso, J. L., \& Parajó, J. C. (2011). Prebiotic potential of a refined product containing pectic oligosaccharides. LWT -Food Science and Technology, 44(8), 1687-1696.

Gullón, P., González-Muñoz, M. J., Domínguez, H., \& Parajó, J. C. (2008). Membrane processing of liquors from eucalyptus globulus autohydrolysis. Journal of Food Engineering, 87(2), 257-265.

Hartmann, R., \& Meisel, H. (2007). Food-derived peptides with biological activity: From research to food applications. Current Opinion in Biotechnology, 18(2), 163-169.

Hentschel, A., Gramdorf, S., Muller, R. H., \& Kurz, T. (2008). Beta-carotene-loaded nanostructured lipid carriers. Journal of Food Science, 73(2), N1-N6. 
Hsieh, C., Huang, Y., Lai, C., Ho, W., \& Ko, W. (2010). Develop a novel method for removing fusel alcohols from rice spirits using Nanofiltration. Journal of Food Science, 75(2), N25-N29.

Jones, O. G., \& McClements, D. J. (2010). Functional biopolymer particles: Design, fabrication, and applications. Comprehensive Reviews in food Science and Food Safety, 9(4), 374-397.

Jones, O. G., Decker, E. A., \& McClements, D. J. (2010). Comparison of proteinpolysaccharide nanoparticle fabrication methods: Impact of biopolymer complexation before or after particle formation. Journal of Colloid and Interface Science, 344(1), 21-29.

Kuhn, R. C., Maugeri Filho, F., Silva, V., Palacio, L., Hernández, A., \& Prádanos, P. (2010). Mass transfer and transport during purification of fructooligosaccharides by nanofiltration. Journal of Membrane Science, 365(1-2), 356-365.

Kuo, P. (2010). The application of nanotechnology to functional foods and nutraceuticals to enhance their bioactivities. In Biotechnology in functional foods and nutraceuticals, B. Debasis, L. Francis \& K. G. Dilip (Eds.), (pp. 447-462) CRC Press.

Lapointe, J.-F., Gauthier, S. F., Pouliot, Y., \& Bouchard, C. R. (2003). Effect of hydrodynamic conditions on fractionation of b-lactoglobulin tryptic peptides using nanofiltration membranes. Journal of Membrane Science, 212(1-2), 55-67.

Liu, Z., Jiao, Y., Wang, Y., Zhou, C., \& Zhang, Z. (2008). Polysaccharides-based nanoparticles as drug delivery systems. Advanced Drug Delivery Reviews, 60(15), 1650-1662.

Livney, Y. D. (2010). Milk proteins as vehicles for bioactives. Current Opinion in Colloid $\mathcal{E}$ Interface Science, 15(1-2), 73-83.

Luo, J., Ding, L., Chen, X., \& Wan, Y. (2009). Desalination of soy sauce by nanofiltration. Separation and Purification Technology, 66(3), 429-437.

Martinez-Ferez, A., Guadix, A., Zapata-Montoya, J. E., \& Guadix, E. M. (2008). Influence of transmembrane pressure on the separation of caprine milk oligosaccharides from protein by cross-flow ultrafiltration. International Journal of Dairy Technology, 61(4), 333-339.

Martinez-Ferez, A., Rudloff, S., Guadix, A., Henkel, C., Pohlentz, G., Boza, J., Guadix, E., \& Kunz, C. (2006) Goats' milk as a natural source of lactose-derived oligosaccharides: Isolation by membrane technology. International Dairy Journal, 16(2), 173-181

Matalanis, A., Jones, O. G., \& McClements, D. J. (2011). Structured biopolymer-based delivery systems for encapsulation, protection, and release of lipophilic compounds. Food Hydrocolloids, 25(8),1865-1880.

Moraru, C. I., Panchapakesan, C. P., Huang, Q., Takhistov, P., Liu, S., \& Kokini, J. L. (2003). Nanotechnology: A new frontier in food science. Food Technology, 57(12), 24-29.

Mozafari, M. R. (2010). Nanoliposomes: Preparation and analysis. Methods in Molecular Biology (Clifton, N.J.), 605, 29-50.

Muchow, M., Schmitz, E. I., Despatova, N., Maincent, P., \& Müller, ,R.H. (2009). Omega-3 fatty acids-loaded lipid nanoparticles for patient-convenient oral bioavailability enhancement. Die Pharmazie, 64(8), 499-504.

Muthukumarappan, K., \& Marella, C. (2010). Membrane processing. In: Mathematical modeling of food processing, Farid, M.M. (Ed.), (pp. 735-758) CRC Press.

Negrão Murakami, A.N., de Mello Castanho Amboni, R.D., Prudêncio, E.S., Amante, E. R., de Moraes Zanotta, L., Maraschin, M., Cunha Petrus, J.C., \& Teófilo, R.F. (2011). Concentration of phenolic compounds in aqueous mate (Ilex paraguariensis A. St. Hil) extract through nanofiltration. LWT - Food Science and Technology, 44(10), 2211-2216. 
Pan, K., Song, Q., Wang, L., \& Cao, B. (2011). A study of demineralization of whey by nanofiltration membrane. Desalination, 267(2-3), 217-221.

Peters, R., Dam, G. t., Bouwmeester, H., Helsper, H., Allmaier, G., Kammer, F. v., Ramsch, R. Solans, C., Tomaniová, M., Hajslova, J., \& Weigel, S. (2011). Identification and characterization of organic nanoparticles in food. Trends in Analytical Chemistry, 30(1), 100-112.

Picot, L., Ravallec, R., Martine, F. - P., Vandanjon, L., Jaouen, P., Chaplain-Derouiniot, M., Guérard. F., Chabeaud, A., LeGal, Y., Martinez Alvarez, O., Bergé J. -P., Piot, J. -M., Batista, I., Pires, C., Thorkelsson, G., Delannoy, C., Jakobsen, G., Johansson, I. \& Bourseau, P. (2010). Impact of ultrafiltration and nanofiltration of an industrial fish protein hydrolysate on its bioactive properties. Journal of the Science of Food and Agriculture, 90(11), 1819-1826.

Pisal, D. S., Kosloski, M. P., \& Balu-Iyer, S. V. (2010). Delivery of therapeutic proteins. Journal of Pharmaceutical Sciences, 99(6), 2557-2575.

Podaralla, S., \& Perumal, O. (2010). Preparation of zein nanoparticles by $\mathrm{pH}$ controlled nanoprecipitation. Journal of Biomedical Nanotechnology, 6(4), 312-317.

Pouliot, Y. (2008). Membrane processes in dairy technology-From a simple idea to worldwide panacea. International Dairy Journal, 18(7), 735-740.

Rahimnejad, M., Mokhtarian, N., \& Ghasemi, M. (2009). Production of protein nanoparticles for food and drug delivery systems. African Journal of Biotechnology, 8(19), 4738-4743.

Rios, G. M., Belleville, M. P., Paolucci, D., \& Sanchez, J. (2004). Progress in enzymatic membrane reactors - a review. Journal of Membrane Science, 242(1), 189-196.

Ron, N., Zimet, P., Bargarum, J., \& Livney, Y. D. (2010). Beta-lactoglobulin-polysaccharide complexes as nanovehicles for hydrophobic nutraceuticals in non-fat foods and clear beverages. International Dairy Journal, 20(10), 686-693.

Roufik, S., Gauthier, S. F., \& Turgeon, S. L. (2007). Physicochemical characterization and in vitro digestibility of $\beta$-lactoglobulin/ $\beta$-Lg f142-148 complexes. International Dairy Journal, 17(5), 471-480.

Sabaté, J., Labanda, J., \& Llorens, J. (2008). Nanofiltration of biogenic amines in acidic conditions: Influence of operation variables and modeling. Journal of Membrane Science, 310(1-2), 594-601.

Sanguansri, P., \& Augustin, M. A. (2006). Nanoscale materials development - a food industry perspective. Trends in Food Science \& Technology, 17(10), 547-556.

Saxena, A., Tripathi, B. P., Kumar, M., \& Shahi, V. K. (2009). Membrane-based techniques for the separation and purification of proteins: An overview. Advances in Colloid and Interface Science, 145(1-2), 1-22.

Sereewatthanawut, I., Baptista, I. I. R., Boam, A. T., Hodgson, A., \& Livingston, A. G. (2011). Nanofiltration process for the nutritional enrichment and refining of rice bran oil. Journal of Food Engineering, 102(1), 16-24.

Shidhaye, S. S., Vaidya, R., Sutar, S., Patwardhan, A., \& Kadam, V. J. (2008). Solid lipid nanoparticles and nanostructured lipid carriers -- innovative generations of solid lipid carriers. Current Drug Delivery, 5(4), 324-331.

Shukat, R., \& Relkin, P. (2011). Lipid nanoparticles as vitamin matrix carriers in liquid food systems: On the role of high-pressure homogenisation, droplet size and adsorbed materials. Colloids \& Surfaces B: Biointerfaces, 86(1), 119-124.

Souto, E. B., \& Müller, R. H. (2006). Applications of lipid nanoparticles (SLN and NLC) in food industry. Journal of Food Technology, 4(1), 90-95. 
Suárez, E., Lobo, A., Alvarez, S., Riera, F. A., \& Álvarez, R. (2009). Demineralization of whey and milk ultrafiltration permeate by means of nanofiltration. Desalination, 241(1-3), 272-280.

Swanson, J. E. (2003). Encyclopedia of food and culture; bioactive food components, Charles Scribner's Sons, New York.

Takacs, L., Korany, K., \& Vatai, G. (2010). Process modelling in the production of low alcohol content wines by direct concentration and diafiltration using nanofiltration membranes. Acta Alimentaria, 39(4),397-412.

Tessier, B., Harscoat-Schiavo, C., \& Marc, I. (2006). Selective separation of peptides contained in a rapeseed (Brassica campestris L.) protein hydrolysate using UF/NF membranes. Journal of Agricultural and Food Chemistry, 54(10), 3578-3584.

Thassu, D., Pathak, Y., \& Deleers, M. (2007). Nanoparticulate drug-delivery systems: an overview. In: Nanoparticulate Drug Delivery Systems, Thassu, D. (Ed.), (pp. 1-31) Informa Heaalthcare.

Ting, B. P. C. P., Gauthier, S. F., \& Pouliot, Y. (2007). Fractionation of $\beta$-lactoglobulin tryptic peptides using spiral wound nanofiltration membranes. Separation Science and Technology, 42(11), 2419-2433.

Tylkowski, B., Tsibranska, I., Kochanov, R., Peev, G., \& Giamberini, M. Concentration of biologically active compounds extracted from Sideritis ssp. L. by nanofiltration. Food and Bioproducts Processing, In Press, Corrected Proof.

Vandanjon, L., Grignon, M., Courois, E., Bourseau, P., \& Jaouen, P. (2009). Fractionating white fish fillet hydrolysates by ultrafiltration and nanofiltration. Journal of Food Engineering, 95(1), 36-44.

Vandanjon, L., Johannsson, R., Derouiniot, M., Bourseau, P., \& Jaouen, P. (2007). Concentration and purification of blue whiting peptide hydrolysates by membrane processes. Journal of Food Engineering, 83(4), 581-589.

Vanneste, J., Sotto, A., Courtin, C. M., Van Craeyveld, V., Bernaerts, K., Van Impe, J., Vandeur, J., Taes, S., \& Van der Bruggen, B. (2011). Application of tailor-made membranes in a multi-stage process for the purification of sweeteners from Stevia rebaudiana. Journal of Food Engineering, 103(3), 285-293.

Vegas, R., Moure, A., Domínguez, H., Parajó, J. C., Alvarez, J. R., \& Luque, S. (2008). Evaluation of ultra- and nanofiltration for refining soluble products from rice husk xylan. Bioresource Technology, 99(13), 5341-5351.

Walha, K., Ben Amar, R., Massé, A., Bourseau, P., Cardinal, M., Cornet, J., Prost, C., \& Jaouen, P. (2011). Aromas potentiality of tuna cooking juice concentrated by nanofiltration. LWT - Food Science and Technology, 44(1), 153-157.

Wang, L., Shao, C., \& Wang, H. (2009). Nanofiltration continuous process control: Recovery of oligosaccharides from streamed soybean waste water. Membrane Science and Technology-Lanzhou-, 29(1), 79-82.

Zhang, Z., Yang, R., Zhang, S., Zhao, H., \& Hua, X. (2011). Purification of lactulose syrup by using nanofiltration in a diafiltration mode. Journal of Food Engineering, 105(1), 112118. 


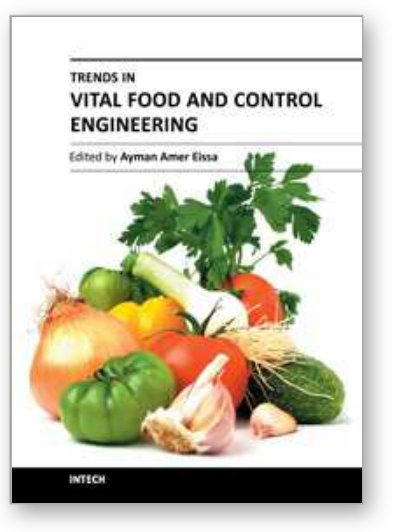

\author{
Trends in Vital Food and Control Engineering \\ Edited by Prof. Ayman Amer Eissa
}

ISBN 978-953-51-0449-0

Hard cover, 290 pages

Publisher InTech

Published online 05, April, 2012

Published in print edition April, 2012

This book is an example of a successful addition to the literature of bioengineering and processing control within the scientific world. The book is divided into twelve chapters covering: selected topics in food engineering, advances in food process engineering, food irradiation, food safety and quality, machine vision, control systems and economics processing. All chapters have been written by renowned professionals working in food engineering and related disciplines.

\title{
How to reference
}

In order to correctly reference this scholarly work, feel free to copy and paste the following:

Vanessa Nieto-Nieto, Silvia Amaya-Llano and Lech Ozimek (2012). Continuous Membrane Bioreactor (CMBR) to Produce Nanoparticles from Milk Components, Trends in Vital Food and Control Engineering, Prof. Ayman Amer Eissa (Ed.), ISBN: 978-953-51-0449-0, InTech, Available from: http://www.intechopen.com/books/trendsin-vital-food-and-control-engineering/continuous-membrane-bioreactor-cmbr-to-produce-nanoparticles-frommilk-components

\section{INTECH}

open science | open minds

\section{InTech Europe}

University Campus STeP Ri

Slavka Krautzeka 83/A

51000 Rijeka, Croatia

Phone: +385 (51) 770447

Fax: +385 (51) 686166

www.intechopen.com

\section{InTech China}

Unit 405, Office Block, Hotel Equatorial Shanghai

No.65, Yan An Road (West), Shanghai, 200040, China

中国上海市延安西路65号上海国际贵都大饭店办公楼 405 单元

Phone: +86-21-62489820

Fax: $+86-21-62489821$ 
(C) 2012 The Author(s). Licensee IntechOpen. This is an open access article distributed under the terms of the Creative Commons Attribution 3.0 License, which permits unrestricted use, distribution, and reproduction in any medium, provided the original work is properly cited. 